\title{
Risks Affecting Hybrid Rice Yield in Bangladesh: Two-tier Approach of Appraisal and Management
}

\author{
A.K.M. Kanak Pervez ${ }^{\text {* }}$, A. A. Shah' ${ }^{2}$, M.E. Uddin ${ }^{3}$, M.N.I. Sarker ${ }^{4}$ and M.M. Islam ${ }^{5}$ \\ Received: 05 $5^{\text {th }}$ October 2020 / Accepted: $14^{\text {th }}$ November 2021
}

\begin{abstract}
Purpose: Bangladesh faces a growing food demand from a growing population under the continuous shrinking of arable land. Most Bangladeshi farmers produce inbred rice. Hybrid rice has been shown, in China, to be far more productive per hectare. Bangladesh cannot feed itself long-term without ample produce of hybrid rice. Yet, fewer Bangladeshi farmers are growing hybrid rice at present; they perceive hybrid rice cultivation as too risky. The present study was conducted to define the yield risks of hybrid rice and develop management strategies to allow hybrid rice to contribute more to food production.
\end{abstract}

Research Method: Both quantitative and qualitative methods were used to evaluate the risks of hybrid rice production from the farmers 'perspective and the experts'. Three hundred fifty-four randomly-sampled hybrid rice farmers were interviewed with key informants, focus group discussions, experts'opinion surveys, and workshops. A fuzzy triangular scale was used in calculating the yield risks of hybrid rice production.

Findings: From the results, unexpected yield performance, germination failure, unavailability of seed in sowing seasons, and crop failure due to pest infestation were identified as the critical yield risks. A regression model determined that education, family income, innovativeness, hybrid rice cultivation experience, and rice selling in public procurement are lower yield risks in growing hybrid rice. Therefore, educated farmers from high-income families, innovative farmers, experienced farmers, and farmers who sell rice in public procurement face lower yield risk in hybrid rice production.

Originality/value: This study mainly identified the critical risk and management strategies for hybrid rice production in Bangladesh. The policy advises encouraging hybrid rice cultivation by reducing yield risk, which is also offered.

Keywords: Agricultural extension; High Yielding Varieties (HYVs); hybrid rice; mixed-method; risks in agriculture

\section{INTRODUCTION}

A steady decrease of arable land, at $1 \%$ per year, together with continued burgeoning population growth, has created food insecurity in Bangladesh (Hasan et al., 2013; Molla, 2016; Shahabuddin, 2016). It is estimated that approximately 0.07 hectares of arable land per capita are required to provide a diversified diet for an individual in a year (Deininger et al., 2017; FAO, 1993). In contrast, the present per capita arable land of Bangladesh is only 0.048 hectares (World Bank, 2019).

\footnotetext{
1*Department of Agronomy and Agricultural Extension, University of Rajshahi, Rajshahi-6205, Bangladesh kp@ru.ac.bd

${ }^{2}$ School of Management and Engineering, Nanjing University of Information Science and Technology (NUIST), No 219, Ningliu Road, Nanjing, Jinagsu 210044, P. R. China

${ }^{3}$ Department of Agricultural Extension and Rural Development, Patuakhali Science and TechnologyUniversity, Dumki, Patuakhali, Bangladesh

${ }^{4}$ School of Political Science and Public Administration, Neijiang Normal University, Neijiang 614112, P. R. China

${ }^{5}$ Department of Management Studies, Patuakhali Science and Technology University, Dumki, Bangladesh

(D)https://orcid.org/0000-0001-7413-9337
} 
Historically and culturally, rice has been the principal food in Bangladesh. Thus, food security in Bangladesh is synonymous with rice production sufficiency (Pervez et al., 2017). The people of Bangladesh consume the highest per capita amount of rice globally, at 489 grams per person per day (Hossain and Yunus, 2016). Rice alone supplies approximately $75 \%$ of calorie intake and about $50 \%$ of protein intake in the country (Pervez, 2018; Pervez et al., 2017).

Some years ago, the Government tried to introduce other crops, especially potatoes and maize, as staple crops. These efforts failed as the people persisted in eating rice as their staple food. Rice price is one of the main determinants for economic stability: even political stability depends on rice prices in Bangladesh. Population growth and the declining trend of cropland create an additional annual demand for approximately two million tons of rice (The Daily Star, 2018).

In 1998, the Government of Bangladesh introduced hybrid rice, using imported seeds from India and China, to meet the rice seed crisis caused by the devastating floods of that year (Husain et al., 2001; Pervez, 2018). As a result, approximately 2.37 thousand hectares of land were planted with imported hybrid rice seeds. The first performance of the hybrid rice in the field was very positive, with at least 1-ton yield per hectare more than the High Yielding Varieties (HYVs) (Pervez, 2018). Later, in a scientific study, it was also proven that hybrid rice could produce at least a 38 percent higher yield than the best-inbred rice in local conditions (Salam et al., 2012). Therefore, hybrid rice seemed to be the key to assuring a supply of food that keeps up with population growth and rice land shrinkage.

Due to the yield advantage of hybrid rice, from 1999, private companies were permitted to import hybrid rice seed. Within a few years, hybrid rice became popular, and the production area peaked in 2007-08, at approximately 0.8 million hectares (Pervez et al., 2017).

However, the area under hybrid rice cultivation began to decline from the following year, reaching 0.635 million hectares in 2014-15 (Pervez et al., 2017). Currently, in Bangladesh, the total area for hybrid rice production is only around $7.05 \%$ of the total area for all rice production (Krishi Diary, 2018). In contrast, China is cultivating hybrid rice on approximately sixty per cent of its total rice production area (Long-ping, 2014). Such a high cultivation proportion of total rice production area for hybrid rice is one primary reason that China is feeding around one-fifth of the global population using just 10 percent of arable land in the world (Li et al., 2009).

Although hybrid rice has a higher yield potential in Bangladesh than the traditional inbred or HYVs, why hybrid rice is so unpopular among most farmers who have switched back to growing inbred or HYV rice in recent years? Some researches have shown that the primary reason is the enormous yield gap of hybrid rice between Bangladesh and China (Pervez et al.,2017; Singh et al., 2015). However, the average harvest of hybrid rice is at least one ton per hectare higher than the best HYV rice in Bangladesh at farmers' level (Krishi Diary, 2018). The yield gap is a function of many factors: including climatic risk, inappropriate input application, and improper management practices.

Scholars in this field have identified several risks associated with hybrid rice adoption in Bangladesh at farmers' level (McFall et al., 2013; Pervez, 2018; Shah et al., 2015; Pervez et al., 2017). The risks seriously affect the extent of hybrid rice adoption in Bangladesh, but few studies have been conducted to identify the risks and assess efforts to manage the risks. Thus, this study was conducted to i) identify and assess the yield risks based on farmers' and experts' perceptions; and ii) develop effective risk management strategies for the catastrophic yield risks.

\section{MATERIALS AND METHODS}

\section{Study approaches:}

The assessment of risks have both qualitative and quantitative dimensions. Thus, both qualitative and quantitative researches are required to study it. So, mixed-method research methodology was selected for triangulation of study findings (Chow et al., 2010). Researchers have used different risk 
management frameworks in their research; (e.g. IRM risk management framework (IRM, 2002) Strategic risk management process (Clarke and Varma, 1999), Australia/ New Zealand standard for risk management (Keey, 1998) etc.). All of the risk management frameworks indicate five steps for risk management. These are: (i) the establishment of the context; (ii) identification of the risks; (iii) analysis of the risk; (iv) assessment of the risk; and (v) treatment (planned management) of the risk. These five stages may be categorized under two broad heads: a) risk assessment (i) to (iv); and b) risk management (5) above (Pervez, 2018). Figure 01 illustrates the detail of the risk management steps and the research methodologies and tools used in the study.

Initially, researchers searched the literature associated with risk in hybrid rice production. Then the researchers used KIIs (Key Informant Interviews) and five FGDs (Focus Group Discussions) with hybrid rice farmers and three FGDs with hybrid rice scientists and extension specialists to identify the risks. A snowball sampling method was used to discover the right subjects for KIIs. After identifying the relevant risks, the probability of each risk item was found by measuring its Cronbach alpha values. A risk statement was selected for use in the study if its Cronbach alpha value was higher than 0.70 , indicating a satisfactory reliability level (Nunnally, 1978).

Then two structured questionnaires were prepared for data collection. These questionnaires were used to conduct surveys both among hybrid rice farmers and among hybrid rice scientists and extension officers in Bangladesh. Eight risks are included in the questionnaire for farmers level survey. For experts (hybrid rice researchers and extension officers who were working in hybrid rice production and extension in Bangladesh), the number of yield risks asked about was 11, because some risks were technical. It was considered that farmers might not be able to assess the highlytechnical risks accurately.

\section{Description of the study area for the farmers- level survey:}

In Bangladesh, hybrid rice is not cultivated in every District or even in all Upazillas (SubDistricts) in a District. Thus, data collection was carried out in three purposively-selected Upazillas: Puthia, Debidwar, and Khoksa, from Rajshahi, Comilla, and Kushtia Districts, respectively.

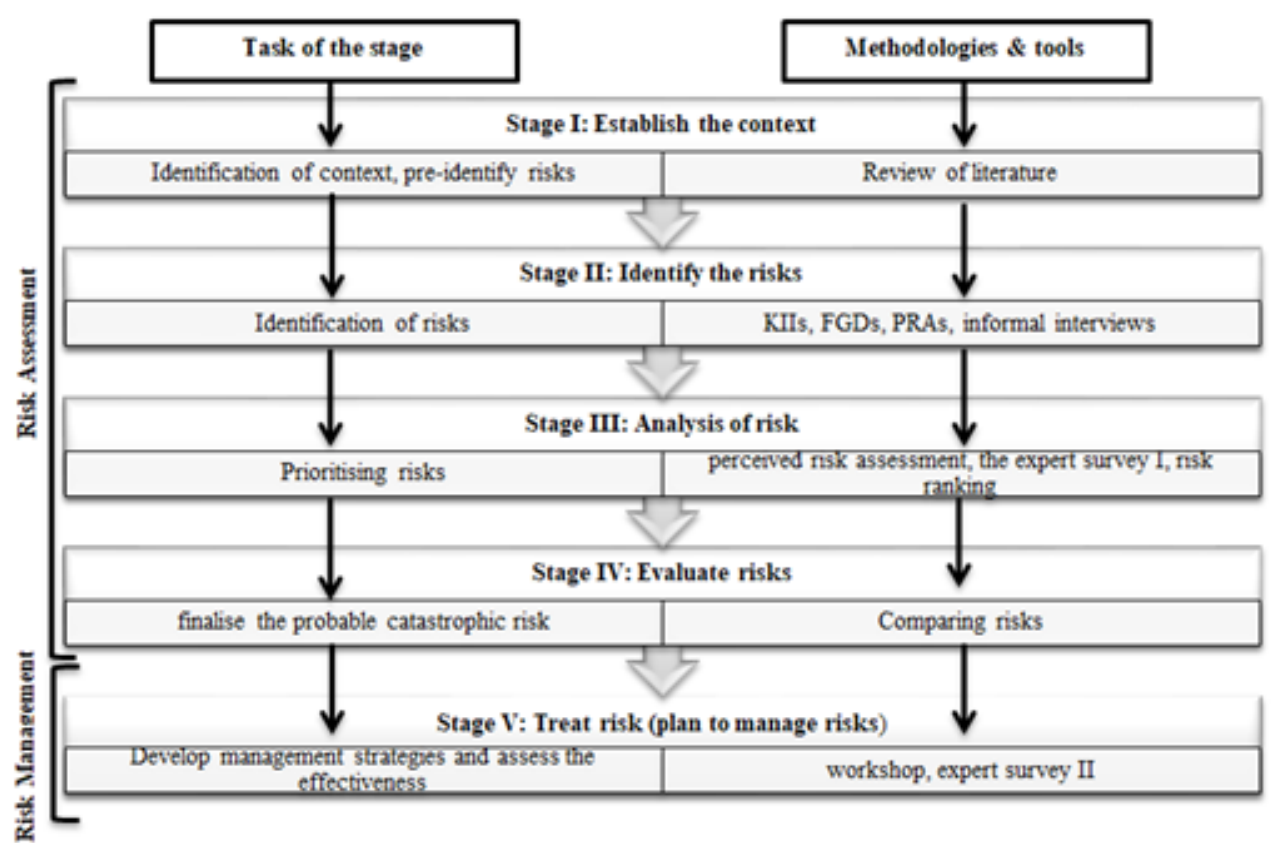

Source: Pervez et al. 2016; Pervez 2018,(modified)

Figure 01: The research methodologies and tools used in the research 
These three Districts are located in three different administrative Divisions of the country. They act as a sample set from the population of hybridrice-growing Upazillas in Bangladesh. These sub-Districts have in common the fact, that the number of hybrid rice cultivation areas in the selected sub-Districts has been declining over time. Thus, they clearly illustrate the problem being studied. According to the Upazilla agriculture offices, over five years, the hybrid rice coverage area has decreased in size by some $15 \%$ in Puthia but by around $72 \%$ in Debidwar. In Khoksha, within one year, the area formerly covered by hybrid rice and replaced by inbred rice accounted for some $38 \%$ of the total area planted with hybrid rice. Therefore, we needed to find out the extent to which unmanaged (or perceived as unmanageable), the risk was leading these farmers to decide to stop planting hybrid rice in such large numbers.

\section{Population and sampling:}

The population was taken into account considering the fact that all were hybrid rice growers of the three purposively-selected Upazillas described above. A total of 4400 growers (farm families) were producing hybrid rice in these three Upazillas in the 2015-16 fiscal years. From the respective Upazilla agriculture offices, the list of these hybrid rice growers was collected. A random sample was determined using an online sample size calculator at a 95\% confidence level with a $5 \%$ margin of error. The actual sample size, thus calculated, used for data collection, was 354 hybrid rice farmers.

\section{Expert level surveys and the workshop:}

Two experts' surveys and an experts' workshop were conducted. Experts' Survey-I (ES-I) examined the risk perceptions of the experts. Based on the ES-I and farmers' perceptions, the researcher selected the top three catastrophic risks. Both survey results showed that two risks were common among the top three risks of the two surveys.

Risk management strategies were developed through a workshop held in the University of Rajshahi, Bangladesh, on May 15 2016. In the workshop, the experts were divided into four sub-groups. Through a brainstorming session, the expert members suggested suiTable 0risk management strategies for each selected risk. Finally, ES-II was conducted to assess the effectiveness of each risk management strategy, based on a five-point scale.

The minimum qualification of the experts was that: (1) they have at least a Master's degree in a relevant field of agriculture, and (2) they are either: i) engaged in research concerning hybrid rice, or ii) involved in a) extension of agricultural services to hybrid rice farmers in Bangladesh; or b) teaching hybrid rice technologies at the tertiary level. Table 01 represents the characteristics of experts who participated in the research.

Table 01: Characteristics of expert members who participated in ES (Expert Survey)-1, ES-2, and the workshop

\begin{tabular}{cccccc}
\hline \multirow{2}{*}{$\begin{array}{c}\text { Survey/ } \\
\text { Workshop }\end{array}$} & \multicolumn{2}{c}{ The highest degree of experts } & \multicolumn{2}{c}{ Organizational involvement of experts } \\
\cline { 2 - 5 } & Masters & PhD. & BRRI $^{1}$ & DAE $^{2}$ & University \\
\hline \multirow{2}{*}{ ES-I } & 11 & 19 & 9 & 6 & 15 \\
& $(36.67 \%)$ & $(63.33 \%)$ & $(30 \%)$ & $(20 \%)$ & $(50 \%)$ \\
Workshop & 6 & 12 & 5 & 3 & 10 \\
& $(33.33 \%)$ & $(66.67 \%)$ & $(27.78 \%)$ & $(16.67 \%)$ & $(55.56 \%)$ \\
ES-II & 6 & 14 & 6 & 3 & 9 \\
& $(30 \%)$ & $(70 \%)$ & $(30 \%)$ & $(15 \%)$ & $(45 \%)$ \\
\hline
\end{tabular}

${ }^{I} B R R I=$ Bangladesh Rice Research Institute, ${ }^{2} D A E=$ Department of Agricultural Extension, Ministry of Agriculture, Bangladesh 
The main reason behind the small number of experts who participated in the surveys and workshops is, the lack of hybrid rice expertise in Bangladesh. Besides, among the few experts identified in this area, many were too busy to attend. Finally, funds were not available to engage more experts for the research. Researchers had to travel to many rural areas across the country to engage with experts, which was costly.

\section{Measurement of yield Risks:}

Using a 5-point Likert scale, farmers were asked to assess the probability of risks or vulnerability mentioned (from "unlikely" to "recurrent") and to assess the potential losses or hazards if the risk occurred (from "insignificant" to "catastrophic"). To calculate the risk score of each item, we used the following equation, adapted from (Kirilenko et al., 2004; Soussan and Arriëns, 2004):

$\mathrm{R}=\mathrm{f}(\mathrm{H} \times \mathrm{V})$

Where $\mathrm{R}=$ Risk, $\mathrm{H}=$ Hazard, and $\mathrm{V}=$ Vulnerability
Although researchers have frequently used the Likert scale in social science, many researchers have also found its limitations. First of all, the traditional range assumes identical differences between two successive scale points, which is not always a correct measure in all cases (Cohen et al., 2002). Therefore, we used a fuzzy-Likert scale for risk measurement, adopted from (Pervez 2018; Pervez et al., 2017; Rivza and Rivza, 2013). Specifically, we used (Li, 2013)'s “fuzzy triangular scale". The fuzzy triangular scale for vulnerability and hazards for this research is shown in Tables 2,3 , respectively.

To calculate the risk score for each item, the fuzzy values were multiplied, based on fuzzy multiplication law (Habibi et al., 2015):

$$
(A \otimes B=(a 1 \otimes b 1, a 2 \otimes b 2, a 3 \otimes b 3)(i i)
$$

The triangular fuzzy values are not real numbers. Therefore, to get the actual value, it was necessary to "de-fuzzyfy" the fuzzy numbers. For this, centroid methods (Ross, 2005) were used (see Appendix A and B).

Table 02: $\quad$ A Fuzzy Triangular Scale (FTS) to assess likelihood/ vulnerability

\begin{tabular}{ccc}
\hline Scale & Characterisation & FTS \\
\hline Unlikely & May occur in a uncommon conditions & $(0,0.125,0.25)$ \\
Rarely & May occur though unlikely & $(0.15,0.30,0.45)$ \\
Irregular & May occur in a year & $(0.35,0.50,0.65)$ \\
Possible & May occur within some months & $(0.55,0.70,0.85)$ \\
Recurrent & May occur in every & $(0.75,0.875,1.0)$ \\
\hline
\end{tabular}

Source:Rivza and Rivza 2013; Pervez 2018; Pervez et al. 2019, (modified)

Table 03: $\quad$ FTS to assess the significance (impact)/ hazards of risks

\begin{tabular}{ccc}
\hline Scale & Characterisation(Losses $\%$ of total business) & FTS \\
\hline Insignificant & up to 1 & $(0,0.0075,0.015)$ \\
Minor & $1-5$ & $(0.005,0.025,0.055)$ \\
Moderate & $5-10$ & $(0.045,0.0775,0.11)$ \\
Critical & $10-25$ & $(0.09,0.195,0.30)$ \\
Catastrophic & More than 25 & $(0.20,0.60,1.0)$ \\
\hline
\end{tabular}




\section{RESULTS AND DISCUSSIONS}

Socio-Demographic Characteristics (SDCs) of hybrid rice farmers:

The SDCs of hybrid rice farmers are summarised in Table 04. Women's participation in hybrid rice production was minimal. The farmers and their families perceive hybrid rice cultivation as risky compared to cultivation of other crops or HYV rice (inbred) production in which, women participation is apparent. Typically, in Bangladesh, most of the farm households are male-headed. A woman farmer only heads the family in the absence of her adult male family members or if they have died or migrated to distant places for employment. Islamic women are raised to obey the male members of their households: father, then husband, then son (Islam et al., 2008).

The educational level of the hybrid rice farmers was low-to-medium. A few growers in the sample have completed a first tertiary degree $(6 \%)$. In Bangladesh, most of educated people do not want to be farmers. Farming is regarded as an occupation for illiterate or less-educated people, a low-status occupation in society (Pervez et al., 2015; Pervez, 2018; Pervez et al., 2019). Thus, a university graduate will not usually choose to enter farming as a career. In this regard, a local leader said, 'If a farmer's child obtains a tertiary education, the graduate will face great social pressure to go to the city and take a highstatus position in a bank or company, or to join a profession or the Bangladesh Civil Service, and not waste his life in the field' (Abdul Malek Mia (55), December 29 2016)

Most of the farmers did not get seed from the State (69.21\%) because the Bangladesh Agricultural Development Corporation (BADC) only produces $5.6 \%$ of the total hybrid rice seed requirement annually (Emmanuel, 2014). Furthermore, Bangladesh Rice Research Institute (BRRI) has been suffering from inadequate human resources: particularly in hybrid rice research (Pervez, 2018; Pervez et al., 2017; Pervez et al., 2019). As a result, BRRI has registered only six hybrid rice varieties, whereas private companies have registered 119 hybrid rice varieties (Pervez et al., 2017).

Similarly, only $31.92 \%$ of hybrid rice growers got the opportunity to sell rice to the State in public procurement schemes. Bangladesh has a problem of gangsters controlling marketing channels for hybrid rice. Therefore, the farmer often receives a very low price if he tries to sell his hybrid rice privately (Pervez, 2018; Pervez et al., 2017; Pervez et al., 2019). When farmers fail to sell their hybrid rice in public procurement, they usually go to intermediaries. These middlemen generally offer low prices to farmers and sell the rice in public procurement schemes themselves because they can arrange better prices than the farmer. Often, they obtain these prices through bribery of the officials administering public procurement (Pervez et al., 2017).

\section{Yield risk in hybrid rice cultivation:}

Most of the farmers perceived medium-to-serious yield risk in cultivating hybrid rice. Only a few farmers $(10 \%)$ felt that they faced little risk in hybrid rice cultivation. Table 05 represents the farmers' feelings about the risk in their hybrid rice farm operations.

Farmers' perception that hybrid rice cultivation is a risky operation restricts its use in Bangladesh. The research reported that $97.50 \%$ of the nonadopters, $94.20 \%$ of de-adopters, $89.20 \%$ of continuing adopters of hybrid rice growers also faced a moderate-to- serious risk during farming (Shah et al., 2015). Thus, during data collection, many farmers said that they would not continue to cultivate hybrid rice.

\section{Risk and risk management strategies in hybrid rice extension:}

Based on the farmers' level and experts' level, results of survey on likelihood and severity; the 
risks were ranked (Table 06). The detailed data sets, with frequency distributions of probability and severity, are shown in Appendices A and B.

According to farmers ' perceptions, the results showed that "Massive germination failure of purchased hybrid rice seeds" is the most serious yield risk in hybrid rice farming. Experts judged that 'Unavailability of good quality hybrid rice seed during sowing seasons' was the most -serious yield risk.

\section{Table 04: $\quad$ SDCs of hybrid rice farmers}

\begin{tabular}{|c|c|c|c|c|c|c|}
\hline $\begin{array}{c}\text { The variable and scoring } \\
\text { technique }\end{array}$ & Types & $\mathrm{n}=354$ & $\%$ & SD & Mean & Mode \\
\hline $\begin{array}{c}\text { Age } \\
\text { (1 for each year) }\end{array}$ & $\begin{array}{c}\text { Young }(\leq 34) \\
\text { Middle aged }(35-57) \\
\text { Old }(\geq 57)\end{array}$ & $\begin{array}{c}61 \\
237 \\
56\end{array}$ & $\begin{array}{l}17.23 \\
66.95 \\
15.82\end{array}$ & 11.42 & 45.61 & 45 \\
\hline $\begin{array}{c}\text { Gender } \\
(1=\text { male, } 0=\text { female })\end{array}$ & $\begin{array}{l}\text { Male } \\
\text { Female }\end{array}$ & $\begin{array}{c}320 \\
34\end{array}$ & $\begin{array}{c}90.40 \\
9.60\end{array}$ & - & - & 1 \\
\hline $\begin{array}{c}\text { Education } \\
(1=1 \text { schooling Yr })\end{array}$ & $\begin{array}{c}\text { Low }(\leq 5) \\
\text { Medium }(6-12) \\
\text { High }(\geq 12)\end{array}$ & $\begin{array}{c}91 \\
242 \\
21\end{array}$ & $\begin{array}{c}25.71 \\
68.36 \\
5.93\end{array}$ & 3.64 & 8.03 & 10 \\
\hline $\begin{array}{l}\text { Annual family Income } \\
\quad \text { (in } 0000 \text { BDT) }\end{array}$ & $\begin{array}{c}\text { Low }(\leq 12.18) \\
\text { Medium }(12.19-32.96) \\
\text { High }(\geq 32.96)-61\end{array}$ & $\begin{array}{c}88 \\
208 \\
58\end{array}$ & $\begin{array}{l}24.88 \\
58.76 \\
16.38\end{array}$ & 10.39 & 22.57 & 20 \\
\hline $\begin{array}{l}\text { Off-farm jobs } \\
\text { (Yes/No) }\end{array}$ & $\begin{array}{l}\text { Yes } \\
\text { No }\end{array}$ & $\begin{array}{l}201 \\
153\end{array}$ & $\begin{array}{l}56.78 \\
43.22\end{array}$ & - & - & 0 \\
\hline $\begin{array}{l}\text { Innovativeness (scoring on } \\
\text { different statements) }\end{array}$ & $\begin{array}{c}\text { Low }(\leq 2.95) \\
\text { Medium }(2.95-10.40) \\
\operatorname{High}(\geq 10.40)\end{array}$ & $\begin{array}{c}42 \\
256 \\
56\end{array}$ & $\begin{array}{l}11.86 \\
72.32 \\
15.82\end{array}$ & 3.72 & 6.68 & 4.00 \\
\hline $\begin{array}{l}\text { Hybrid rice cultivation } \\
\text { experience }(1=1 \mathrm{Yr})\end{array}$ & $\begin{array}{c}\text { Low }(\geq 1) \\
\text { Medium }(2-5) \\
\text { High }(\geq 5)\end{array}$ & $\begin{array}{c}119 \\
215 \\
20\end{array}$ & $\begin{array}{c}33.62 \\
60.73 \\
5.65\end{array}$ & 1.77 & 2.69 & 1 \\
\hline $\begin{array}{c}\text { Source of seed }(1=\text { gov., } \\
0=\text { others })\end{array}$ & $\begin{array}{c}\text { Non-gov. source } \\
\text { Governmental source }\end{array}$ & $\begin{array}{l}245 \\
109\end{array}$ & $\begin{array}{l}69.21 \\
30.79\end{array}$ & - & - & 0 \\
\hline $\begin{array}{l}\text { Rice selling in Public } \\
\text { Procurement (Yes/No) }\end{array}$ & $\begin{array}{l}\text { No } \\
\text { Yes }\end{array}$ & $\begin{array}{l}241 \\
113\end{array}$ & $\begin{array}{l}68.08 \\
31.92\end{array}$ & - & - & 0 \\
\hline $\begin{array}{l}\text { NGO loan access } \\
\quad(\text { Yes/No) }\end{array}$ & $\begin{array}{l}\text { No } \\
\text { Yes }\end{array}$ & $\begin{array}{l}170 \\
184\end{array}$ & $\begin{array}{l}48.02 \\
51.98\end{array}$ & - & - & 1 \\
\hline
\end{tabular}

Table 05: Distribution of the respondents based on the yield risk score

\begin{tabular}{ccccc}
\hline Categories & $\mathrm{f}(\mathrm{n}=354)$ & $\%$ & $\mathrm{M}$ & $\mathrm{SD}$ \\
\hline Little risk $(<\mathrm{M}-\mathrm{SD})$ & 35 & 9.89 & & \\
Moderate risk (M-SD to M+SD) & 265 & 74.86 & 0.9247 & 0.63001 \\
Serious risk $(>\mathrm{M}+\mathrm{SD})$ & 54 & 15.25 & & \\
\hline
\end{tabular}


Table 06: The risks in hybrid rice cultivation, score and the rank order

\begin{tabular}{lcccc}
\hline \multirow{2}{*}{\multicolumn{1}{c}{ Risks }} & \multicolumn{2}{c}{ Farmers' view } & \multicolumn{2}{c}{ Experts' view } \\
\cline { 2 - 5 } & Score & Rank & Score & Rank \\
\hline 1. Massive germination failure of purchased seeds & 47.984 & 1 & 3.327 & 3 \\
2. Crop failure in high diseases and pests infestation & 42.2004 & 2 & 1.6306 & 5 \\
3. Quality seed crisis during sowing seasons & 42.0567 & 3 & 5.1662 & 1 \\
4. Unexpected yield performance of hybrid varieties & 39.7137 & 4 & 4.9921 & 2 \\
5. Failure of pesticides in controlling pest attack & 37.7192 & 5 & 1.1862 & 6 \\
6. Yield loss due to sensitive fertiliser dosses & 25.3705 & 6 & 0.7205 & 9 \\
7. Crop failure due to sensitive management & 22.7361 & 7 & 0.6116 & 10 \\
8. Failure of irrigation pump during the crop season & 18.8819 & 8 & 1.1839 & 7 \\
9. High shattering loss & $*$ & $*$ & 0.7462 & 8 \\
10. Production failure due to climatic hazards & $*$ & $*$ & 1.9864 & 4 \\
11. Foolish use of $\mathrm{F}_{2}$ seeds by farmers & $*$ & $*$ & 0.3357 & 11 \\
\hline
\end{tabular}

Source: Field survey, *=Not included in farmers survey

\section{Massive germination failure of purchased hybrid rice seeds}

Hybrid rice growers in south Asia commonly experience a germination failure. The mixture of other rice varieties with hybrid rice seeds and inert material among the hybrid seeds lead to poor germination (Zakirah and Abu 2015). As the seed trade is a seasonal business, many entrepreneurs offer seed in the village markets: they do not care about developing repeat customers and, when the seed does not germinate, the farmers cannot find them to seek redress as they have no shops (Pervez et al., 2017). Such temporary suppliers have a strong economic incentive to sell rubbish seeds and then disappear. Farmers in Bangladesh, primarily illiterate, cannot distinguish between fake seeds and quality seeds.

There is a lot of evidence in Bangladesh that farmers quit hybrid rice cultivation due to the high rate of failure of germination of the seeds when planted (Pervez 2018). Research brought out the seed quality of 15 hybrid rice seed suppliers, with seeds from different companies, and showed that only 37.7 to $85.7 \%$ of seeds were healthy (Akter and Hossain 2015).
A unique 'training program on hybrid rice' will be a suiTable 0ex-ante risk management strategy (Table 07). Farmers' training on hybrid rice production increased profits in Vietnam (Trong and Napasintuwong, 2015), and in the Philippines (Miguel et al. 2021). Therefore, the Department of Agricultural Extension (DAE) should initiate specialized hybrid rice training for farmers as they have no training program for hybrid rice cultivation available to them otherwise.

A recent study has also traced the evidence of hybrid rice crop failure due to diseases and pest infestation (Shah et al., 2015). Hybrid rice is more susceptible to certain diseases and pests than conventional rice (David 2006; Kuyeket al., 2000). This susceptibility can be overcome through proper management techniques. A key informant from Bangladesh Rice Research Institute (BRRI), a rice scientist, said, "some diseases, like Sheath blight, Bacterial Leaf Bloch (BLB) and Blast, in Boro season, or insects like Stem borer and Brown Plant Hopper (BPH), are common in hybrid rice fields. Therefore, we have to make the necessary preparations [to protect] against the said pests and diseases" (December 27 2016). 


\begin{tabular}{|c|c|c|c|c|c|c|}
\hline \multirow{2}{*}{ Risk Management strategies } & \multicolumn{5}{|c|}{ Effectiveness } & \multirow{2}{*}{$\begin{array}{l}\text { Total } \\
\text { score }\end{array}$} \\
\hline & 1 & 2 & 3 & 4 & 5 & \\
\hline \multicolumn{7}{|l|}{ Ex ante strategies } \\
\hline 1. Introduction of the guarantee card for hybrid seed & 1 & 2 & 9 & 6 & 2 & 66 \\
\hline $\begin{array}{l}\text { 2. Farmers' knowledge development about the germination test and } \\
\text { the accepTable 0percentage }\end{array}$ & 0 & 3 & 7 & 7 & 3 & 70 \\
\hline 3. Area specific hybrid rice variety development & 1 & 1 & 4 & 11 & 3 & 74 \\
\hline $\begin{array}{l}\text { 4. Introduction of seed replacement facilities for low rate } \\
\text { germination }\end{array}$ & 1 & 0 & 13 & 5 & 1 & 65 \\
\hline $\begin{array}{l}\text { 5. Farmers' training program on hybrid rice production and } \\
\text { seedling management }\end{array}$ & 1 & 1 & 4 & 10 & 4 & 75 \\
\hline \multicolumn{7}{|l|}{ Ex post strategies } \\
\hline 1. Provision of money reimbursement for germination failure & 0 & 1 & 11 & 7 & 1 & 68 \\
\hline $\begin{array}{l}\text { 2. Adopting suiTable } 0 \mathrm{crop} / \text { varieties by farmers to mitigate } \\
\text { immediate loss }\end{array}$ & 1 & 5 & 5 & 7 & 2 & 64 \\
\hline $\begin{array}{l}\text { 3. Provision of punishment for the low-quality seed producing } \\
\text { companies }\end{array}$ & 0 & 1 & 8 & 7 & 4 & 74 \\
\hline 4. Provision of compensation to farmers for a low yield & 0 & 1 & 9 & 8 & 2 & 71 \\
\hline
\end{tabular}

Crop failure due to serious diseases and pest infestation

At the time of hybrid rice development in China, the priority was placed on increasing of yield. As hybrid rice areas became more extensive, the same problem of diseases and pests arose. In China, the occurrence of Whiteback Planthopper (WBPH), bacterial blight, leaf roller (LR), sheath blight (ShB), Stem borer and viral infections were higher in hybrid varieties than in the conventional types (Mew et al., 1988).

During data collection, many farmers also talked about their experience with disease and insect attacks in their hybrid rice fields. In a focus group discussion, a former hybrid rice farmer said, "For the last few years, I have not continued my hybrid rice cultivation. Three years back, my cultivated hybrid rice was infected by diseases. I went to the agricultural office, and they prescribed a pesticide. I sprayed according to their instructions, but I did not find it effective"'(Abdus Sukur (43), hybrid rice farmer, December 30 2016).
'Introduction of hybrid rice-based Farmer Field Schools (FFSs)' and 'introduction of disease and pest-resistant plant varieties' have been suggested as essential ex-ante risk management strategies in hybrid rice production (Table 08). Many hybrid varieties are imported, so that various plant diseases and pests can be introduced into the country through imported seeds if seed quarantine facilities are weak. In contrast, the risk's considerable ex-post risk management strategies are 'ensuring frequent field visits by extension agents during rice season' and 'punishment provision for low-quality and environmentally-unfriendly-pesticide-producing companies'.

In Bangladesh, low availability of hybrid rice seeds decreases hybrid rice adoption as an innovation (Molla 2016; Mottalebet al., 2015; Pervez et al., 2019). Farmers hardly ever get accepTable 0quality hybrid rice seeds (Husain et al., 2001). The unavailability of seeds is a key barrier towards the wider cultivation of hybrid 
rice. (Pervez et al., 2017). Among the hybrid seeds in the market, only $15 \%$ were of sufficient quality for production (Hasan, 2010).

Bangladesh Agricultural Development Corporation (BADC) is the only State agency that produces hybrid rice seeds. The BADC's seed price is lower than that of seeds produced by private seed companies. Therefore, most farmers prefer to buy BADC seeds. During a PRA, a local farmers' leader stated, "Actually, BADC produces a small amount of seeds compared to the actual demand. Last year, farmers made a long queue on seed collection day, but by the end of the day, many people had still failed to get any seed" (Abdul Quddus (37), farmer, January 6 2017).

Among the risk management strategies, adequate seed production from the State (e.g. BADC, DAE) was selected as the best strategy (Table
09). This is the best opportunitiy we have to solve the quality seed crisis. To maintain seed quality, we need to increase cooperation among three organisations, i.e. DAE, BADC, BRRI, and to introduce frequent monitoring of the seed quality in the private market. Contract farmers could produce hybrid rice seed under the supervision of BRRI, DAE and BADC.

Identifying local parental lines are essential to produce local hybrid rice seed varieties (Ansari, 2015; Joshi and Ali, 2021).). Most imported varieties do not show similar results to those in their native countries. Therefore, the experts recommend developing new types through the identification of local parental lines. On the other hand, 'Smart crop calendar introduction' can be a suiTable 0ex-post risk management strategy for the risks. Smart crop calendar means the introduction of different high-value crops in a year.

Table 08: $\quad$ Management strategies for crop failure due to high diseases and pests infestation

\begin{tabular}{|c|c|c|c|c|c|c|}
\hline \multirow{2}{*}{ Risk Management strategies } & \multicolumn{5}{|c|}{ Effectiveness } & \multirow{2}{*}{$\begin{array}{l}\text { Total } \\
\text { score }\end{array}$} \\
\hline & 1 & 2 & 3 & 4 & 5 & \\
\hline \multicolumn{7}{|l|}{ Ex ante strategies } \\
\hline 1. Introduction of disease pest resistant varieties & 0 & 2 & 5 & 9 & 4 & 75 \\
\hline $\begin{array}{l}\text { 2.Strengthening extension support for adoption of suiTable Orisk } \\
\text { management technology }\end{array}$ & 1 & 4 & 8 & 5 & 2 & 63 \\
\hline 3. Diseases and pests management training for hybrid rice production & 1 & 2 & 9 & 7 & 1 & 65 \\
\hline 4. Introduction of hybrid based FFSs & 0 & 0 & 4 & 8 & 8 & 84 \\
\hline 5. Ensure appropriate seed treatment & 1 & 5 & 7 & 7 & 0 & 60 \\
\hline $\begin{array}{l}\text { 6. Ensure strict seed quarantine to shield access of any disease and } \\
\text { pests from imported hybrid }\end{array}$ & 0 & 3 & 5 & 12 & 0 & 69 \\
\hline
\end{tabular}

Ex post strategies

1. Effective plant protection chemicals introduction

$\begin{array}{llllll}1 & 2 & 11 & 6 & 0 & 62 \\ 1 & 3 & 9 & 5 & 2 & 64 \\ 2 & 1 & 6 & 10 & 1 & 67 \\ 1 & 2 & 4 & 10 & 3 & 72\end{array}$

2. Increasing perching number in hybrid rice fields

3. Punishment provision for low quality and harmful pesticides producing companies

4. Ensure frequent field visits by extension agents during rice seasons 


\section{Table 09: $\quad$ Risk management strategies for unavailability of hybrid seed}

\begin{tabular}{|c|c|c|c|c|c|c|}
\hline \multirow{2}{*}{ Risk Management strategies } & \multicolumn{5}{|c|}{ Effectiveness } & \multirow{2}{*}{$\begin{array}{l}\text { Total } \\
\text { score }\end{array}$} \\
\hline & 1 & 2 & 3 & 4 & 5 & \\
\hline \multicolumn{7}{|l|}{ Ex ante strategies } \\
\hline 1. Adequate seed production from government (e.g. BADC, DAE) & 0 & 0 & 7 & 11 & 2 & 75 \\
\hline $\begin{array}{l}\text { 2. Farmers' training and capability building program on hybrid seed } \\
\text { production }\end{array}$ & 1 & 2 & 5 & 9 & 3 & 71 \\
\hline $\begin{array}{l}\text { 3. Developing new hybrids through the identification of local parental } \\
\text { lines }\end{array}$ & 0 & 3 & 5 & 6 & 6 & 75 \\
\hline $\begin{array}{l}\text { 4. Prior assessment of seed demand for hybrid rice production by } \\
\text { DAE }\end{array}$ & 0 & 1 & 13 & 4 & 2 & 67 \\
\hline 5. Introduction of the advance seed booking system & 1 & 1 & 6 & 8 & 4 & 73 \\
\hline \multicolumn{7}{|l|}{ Ex post strategies } \\
\hline 1. Alternate high yielding crops selection & 1 & 4 & 10 & 5 & 0 & 59 \\
\hline 2. Smart crop calendar introduction & 0 & 0 & 6 & 11 & 3 & 77 \\
\hline
\end{tabular}

Unexpected yield performance of hybrid varieties

In Bangladesh, yield fluctuation is very common for hybrid rice production (Haque et al., 2015; Pervez, 2018; Shah et al., 2015). Very often, hybrid rice growers do not get as much rice harvest as they expect, so, they cannot make a profit on selling what they grow. This occurs due to reliance on imported rice seeds which do not adapt well to the environment in Bangladesh. Thus, disappointing yields are a significant risk of hybrid rice production in Bangladesh. A farmer, during data collection, described his experience with the problem: "We bought seeds from a private company, They said that the yield would be around 7.5-8.0 tons per hectare: but the yield was only 5.0 tons per hectare" (Md. Sumon Mia (25), farmer, April 2 2017'.

According to government rules, every imported variety of hybrid rice seed needs to be registered by SCA. Due to a lack of molecular technology, SCA is unable to maintain the quality of the parental line of the imported hybrid rice varieties. Therefore, ensuring the molecular availability of the appropriate technology is essential for maintaining the quality of the parental lines.
Crop insurance is regarded as a robust risk management strategy in many countries and Bangladesh (Habiba and Shaw, 2013). During data collection, a key informant explained, " $A n$ insurance facility [can] potentially manage the risk of climate change, market failure etc. So, if we can introduce insurance facilities in hybrid rice cultivation in this country, farmers can manage the risks easily" (Professor, University of Rajshahi).

The correlation between Socio-Demographic Characteristics (SDCs) of the hybrid rice growers and their perceived yield risk score:

Table 011 indicates the regression results of the SDCs of hybrid rice farmers and their perceived yield risk score in hybrid rice production. Among the independent variables, educational level, annual family income, innovativeness, hybrid rice cultivation experience and rice vending to the Government show significant negative relation $(\mathrm{p}<0.05)$ with a perceived risk score of hybrid rice farmers. Other selected variables did not show any significant association with risks in hybrid rice cultivation $(\mathrm{p}>0.05)$. 


\section{Table 010: $\quad$ Risk management strategies for unexpected yield performance of hybrid varieties}

\begin{tabular}{|c|c|c|c|c|c|c|}
\hline \multirow{2}{*}{ Risk Management strategies } & \multicolumn{5}{|c|}{ Effectiveness } & \multirow{2}{*}{$\begin{array}{l}\text { Total } \\
\text { score }\end{array}$} \\
\hline & 1 & 2 & 3 & 4 & 5 & \\
\hline \multicolumn{7}{|l|}{ Ex ante strategies } \\
\hline 1. Introducing crop insurance facilities for hybrid rice production & 0 & 2 & 11 & 7 & 0 & 65 \\
\hline $\begin{array}{l}\text { 2. Quality maintained by SCA for imported parental lines (CMS } \\
\text { and R lines) through molecular approaches }\end{array}$ & 0 & 3 & 4 & 9 & 4 & 74 \\
\hline 3. Frequent monitoring of stored seed health from Government & 0 & 5 & 9 & 4 & 2 & 63 \\
\hline $\begin{array}{l}\text { 4. Training facilities development for quality management } \\
\text { technologies }\end{array}$ & 1 & 5 & 4 & 9 & 1 & 64 \\
\hline $\begin{array}{l}\text { 5. Awareness campaigning from extension agents about the use of } \\
\mathrm{F}_{2} \text { generation }\end{array}$ & 3 & 6 & 8 & 2 & 1 & 52 \\
\hline $\begin{array}{l}\text { 6. Practicing mixed cropping by farmers to mitigate loss (e.g. rice- } \\
\text { fish culture) }\end{array}$ & 2 & 8 & 4 & 6 & 0 & 54 \\
\hline \multicolumn{7}{|l|}{ Ex post strategies } \\
\hline $\begin{array}{l}\text { 1. Arranging a provision for compensation by the Government } \\
\text { from the low-quality seed companies }\end{array}$ & 1 & 3 & 10 & 5 & 1 & 62 \\
\hline 2. Ensure intensive extension supports during crop season/s & 1 & 2 & 9 & 4 & 4 & 68 \\
\hline $\begin{array}{l}\text { 3. Punishment provision for companies for low seed performances } \\
\text { (e.g. cancelling license) }\end{array}$ & 0 & 3 & 10 & 5 & 2 & 66 \\
\hline $\begin{array}{l}\text { 4. Arranging a field tour during cultivation to a successful farmers' } \\
\text { plot }\end{array}$ & 2 & 3 & 5 & 9 & 1 & 64 \\
\hline
\end{tabular}

Table 011: Regression results for perceived risk and SDC of hybrid rice farmers

\begin{tabular}{lccccc}
\hline \multicolumn{1}{c}{ SDC } & $\mathrm{B}$ & Std. Error & Beta & $\mathrm{t}$ & Sig. \\
\hline (Constant) & 1.882 & .148 & & 12.680 & .000 \\
Age & .001 & .002 & .020 & .526 & .599 \\
Gender & -.065 & .081 & -.030 & -.794 & .428 \\
Educational level & -.043 & .009 & -.250 & -4.763 & .000 \\
Annual family income & -.014 & .003 & -.238 & -5.255 & .000 \\
Off firm job & -.099 & .059 & -.078 & -1.697 & .091 \\
Innovativeness & -.015 & .007 & -.091 & -2.229 & .026 \\
Hybrid rice cultivation experience & -.040 & .019 & -.112 & -2.105 & .036 \\
Source of hybrid rice seeds & .013 & .070 & .009 & .183 & .855 \\
Rice selling in PP & -.209 & .069 & -.155 & -3.027 & .003 \\
Loan from NGO & .079 & .058 & .062 & 1.366 & .173 \\
\hline
\end{tabular}


Educated farmers can maintain their connection with extension agents. In addition, they can use mass media, e.g. newspaper, television, radio, internet. Therefore, they can acquire the latest information regarding cultivation and market information. A similar relation between diabetic risk and educational level was also found (Pádua et al., 2013). The findings also accord with the results of other researches (Brunello, 2002; Guisoet al., 2003; Pervez et al., 2019).

Similarly, farmers from families with a higher income have a greater level of cosmopolitanism and interaction with innovative people in the society in Bangladesh. Hybrid rice farmers from higher-income families have other income sources. Therefore, they can better afford to lose money if hybrid rice production risks materialize. A significant negative relationship between disaster risks and the income of the people was also observed (Kellenberg and Mobarak 2008). Other researchers also mentioned similar findings (Anbarciet al., 2005; Skidmore, 2001).

Innovative farmers faced less risk in hybrid rice production than others. Other researchers also found an inverse relationship between creativity and risk perception (Hirunyawipada and Paswan, 2006; Sorescu and Spanjol, 2008). Of course, creative people tend to think that they can craft a solution to any problem and, often, they can do so.

Experienced people usually have faced unwanted situations and gained the confidence to manage any risk. Experienced farmers can take necessary action earlier than the fresh can. In the case of agricultural machinery-related risk factors, risks are negatively correlated with work experience (Caffaroet al.,2018). Experienced people generally remain safe in an insecure situation; therefore, they do not fear some risk (Rogers et al., 2000). Farmers who sold their hybrid rice to the State (Public Procurement) faced little risk.

\section{CONCLUSIONS AND RECOMMENDATIONS}

From our findings, 'Introducing crop insurance facilities for hybrid rice production' was suggested in data collection as a risk management strategy. The Government should take necessary actions regarding insurance to change farmers' decision not to grow hybrid rice.

Rice experts and ordinary farmers say that the BADC is not producing or importing enough hybrid rice seeds. Therefore, BADC should produce hybrid seeds in cooperation with the DAE through contract growers. From our findings, most of the catastrophic yield risks are related to seeds. Therefore, the Seed Certification Agency (SCA) should undertake robust screening and monitoring of seed in the private markets to maintain overall seed quality.

DAE should introduce hybrid-rice-based Farmers' Field Schools (FFSs), to show the farmers how to reduce the high level of pest infestation in the hybrid rice fields. Agricultural extension agents should visit hybrid rice fields frequently to look for signs of pests and diseases that farmers do not know about. Frequent monitoring of the field ensures early diagnosis of diseases and must help to protect crops

In Bangladesh, few area-specific hybrid rice varieties are available. Therefore, extensive area-specific variety development must use suiTable 0technology to identify appropriate hybrid rice varieties for each particular area. The Government should begin this work of hybrid rice variety development.

Socio-demographic factors (e.g., education, annual family income, innovativeness, hybrid rice cultivation experience, and rice selling experience in public procurement schemes) contributed to risk reduction. Therefore, a part of the Government's policy to support hybrid rice cultivation should be the improvement of farmers' overall socioeconomic conditions through measures like improving the overall educational level of farmers.

Finally, based on the findings, the Government should increase investment in hybrid rice research, for example, by establishing an autonomous research institute for hybrid rice only. In addition, training for extension agents in hybrid rice production is needed to assist farmers more effectively. 


\section{REFERENCES}

Ansari, A., Hossain, M.J. and Hasan, M.J. (2015). Breeding programs for locally developed hybrid rice and present scenario in Bangladesh. In Proceedings: of $4^{\text {th }}$ International Conference on Agriculture \& Horticulture, Beijing, July 13-15, 2015.

Akter, M.and Hossain, I. (2015). Quality of some hybrid seeds of rice and control of seed borne fungi in Bangladesh. Journal of the Bangladesh Agricultural University13 (2), pp.161-168.

Anbarci, N.,Escaleras, M. andRegister, C.A. (2005). Earthquake fatalities: the interaction of nature and political economy. Journal of Public Economics, 89 (9-10): pp. 1907-1933. https://doi. org/10.1016/j.jpubeco.2004.08.002

World Bank. (2019). Arable land (hectares per person). Available online: https://data.worldbank.org/ indicator/AG.LND.ARBL.HA.PC?locations=BD (accessed on August 6 2019).

Brunello, G. (2002). Absolute risk aversion and the returns to education. Economics of Education Review, 21(6),pp. 635-640.

Caffaro, F., Roccato, M., Micheletti, C. and Cavallo, E. (2018). Falls from agricultural machinery: risk factors related to work experience, worked hours, and operators' behavior. Human factors, 60(1),pp. 20-30, https://doi.org/10.1177/0018720817738591

Chow, M., Quine, S.and M. Li. (2010). The benefits of using a mixed methods approach-quantitative with qualitative-to identify client satisfaction and unmet needs in an HIV healthcare centre. AIDS care, 22 (4),pp. 491-498.

Clarke, C.J.and Varma, S. (1999). Strategic risk management: the new competitive edge. Long Range Planning 32 (4),pp. 414-424, https://doi.org/10.1016/S0024-6301(99)00052-7

Cohen, L., Manion L. and Morrison, K. (2002). Research methods in education. Routledge, New York, USA.

David, C.C. (2006). The Philippine Hybrid Rice Program: A case for redesign and scaling down. Research Paper Series, Manila: Philippine Institute for Development Studies

Deininger, K., S.Savastano and Xia, F. (2017). Smallholders' land access in Sub-Saharan Africa: A newlandscape? Food Policy, 67,pp. 78-92, https://doi.org/10.1016/j.foodpol.2016.09.012

Emmanuel, J. (2014). Bangladesh-planting seed report, Washington, DC: Global Agricultural Information Network.

Guiso, L.,Haliassos, M. and Jappelli, T. 2003. Equity culture: Theory and cross-country evidence. Economic Policy, 18 (36),pp. 123-170.

Habiba, U. and Shaw, R. (2013). Crop Insurance as Risk Management Strategy in Bangladesh. In: R. Shaw, Mallick, F. and Islam, A.I., Disaster Risk Reduction Approaches in Bangladesh (pp. 281-305), New York: Springer.

Habibi, A., Jahantigh, F.F.and Sarafrazi, A.( 2015). Fuzzy Delphi technique for forecasting and screening items. Asian Journal of Research in Business Economics and Management, 5(2),pp. 130-143, http://dx.doi.org/10.5958/2249-7307.2015.00036.5 
Haque, M.M., Pramanik, H.R.,Biswas, J.K.,Iftekharuddaula, K. andHasanuzzama, M. (2015). Comparative performance of hybrid and elite inbred rice varieties with respect to their source-sink relationship. The Scientific World Journal, 2015, pp. 1-11, http://dx.doi. org/10.1155/2015/326802

Hasan, A. A. M., Bala, B. K., and Rowshon, M. K. (2014). Thin layer drying of hybrid rice seed. Engineering in Agriculture, Environment and Food, 7(4), pp.169-175.

Hasan, M., Hossain, M., Bari, M., andIslam. M. (2013). Agricultural land availability in Bangladesh. Dhaka, Bangladesh: SRDI.

Hirunyawipada, T. and Paswan, A.K. (2006). Consumer innovativeness and perceived risk: implications for high technology product adoption. Journal of Consumer Marketing,23(4), pp.182-198.

Hossain, M.andYunus, M. (2016). Estimates of per capita consumption of food grains in Bangladesh. Bangladesh Development Studies, 39 (1-2), pp. 103-116.

Husain, A.M., Hossain, M. and Janaiah, A. (2001). Hybrid rice adoption in Bangladesh: a socioeconomic assessment of farmers' experiences,Economic Studies, XV, pp.154-206, http:// hdl.handle.net/10361/12492

The Daily Star, (2018). Hybrid rice to feed rising population: analysts, The Daily Star, November 28, 2018.

IRM. (2002). A Risk Management Standard, London: Institute of Risk Management (IRM)

Islam, M., Ali, R.,Salehin, M. and Islam. A. (2008). Rural women and poverty: A study on the role of RDRS for poverty alleviation in Bangladesh. Journal of the Bangladesh Agricultural University, $6(2)$, pp.415-421.

Joshi, K. D., \& Ali, J. (2021). Role of IRRI in developing hybrid rice technology development and promotion in Nepal. In Proceedings of Stakeholders Workshop on Hybrid Variety Development in Nepal (p. 52).

Keey, R. (1998). Australia/New Zealand risk management standard, In D. Elms, (Ed.) Owning the future: Integrated risk management in practice, p.91.

Kellenberg, D.K.andMobarak, A.M. (2008). Does rising income increase or decrease damage risk from natural disasters? Journal of Urban Economics, 63(3), pp.788-802.

Kirilenko, A., Alcamo, J., Endejan, M., Golubev, G. andDronin, N. (2004). Modeling the impact of climate changes on agriculture in Russia. In Proceedings of Dokl. Earth Sci, pp. 682-685.

Krishi Diary (2018). Agricultural Information Services (AIS), Dhaka: People Republic of Bangladesh.

Kuyek, D., Zamora O. and Quijano, R. (2000). Hybrid rice in Asia: an unfolding threat. Current trends in agricultural R\&D. Biothai (Thailand): GRAIN pp.1-20.

Li, J., Xin, Y. and Yuan. L. (2019). Hybrid rice technology development: ensuring China's food security. Intl Food Policy Res Inst: Vol. 918.

Li, Q. (2013). A novel Likert scale based on fuzzy sets theory. Expert Systems with Applications, 40 (5), pp.1609-1618,https://doi.org/10.1016/j.eswa.2012.09.015

Long-ping, Y. (2014). Development of hybrid rice to ensure food security. Rice Science, 21 (1) pp.1-2. 
McFall, W.A., Magnan, N.and Spielman, D.J. (2013). Hybrid Rice as a Pro-Poor Technology? Evidence from Bangladesh, Agricultural and Applied Economics Association. Annual Meeting, August 4-6, 2013, Washington, D.C., USA.

Mew, T., Wang, F., Wu, J., Lin, K. and Khush, G. (1988). Disease and insect resistance in hybrid rice. In: S.S. Virmani, Heterosis and Hybrid Rice Breeding. Monographs on Theoretical and Applied Genetics, (pp. 189-200), Berlin: Springer.

Miguel, C. B., Sarmiento, J. M. P., Estaña, L. M. B., Limpoco, M. A. A. A., Calag, V. B., \& Novero, A. U. (2021). Neighborhood Effects in Hybrid Rice Adoption in Davao del Sur, Philippines. Philippine Journal of Science, 150(6A), 1461-1473.

Molla, M.A. (2016).1\% arable land lost each year. The Dhaka Tribune June 172016.

Mottaleb, K.A., Mohanty, S. and Nelson, A. (2015). Factors influencing hybrid rice adoption: a Bangladesh case. Australian Journal of Agricultural and Resource Economics, 5, pp.258-274. https://doi.org/10.1111/1467-8489.12060.

Nunnally, J. (1978). Psychometric methods. New York: McGraw-Hill..FAO. (1993). Soil Loss Accelerating Worldwide. Rome: Food and Agriculture Organization (FAO).

Pádua, M., Santos, J. and Horta, H. (2013). Is there a link between education, risk perception, and health outcomes in diabetes in the context of primary intervention among the elderly population. In Proceedings of ALTEC conference,27-31st October, 2013, Lisbon, Portugal. pp. 27-31.

Pervez,A.K.M.K, Gao, Q. and Uddin, M.E. (2016). The management of agricultural risk in Bangladesh: A proposed process. Asian Journal of Agricultural Extension, Economics \& Sociology, 12(1), pp. 1-13.

Pervez, A.K.M.K. (2018). A Study of the Risk Management Strategy for Hybrid Rice Production in Bangladesh. PhD thesis, Beijing: China Agricultural University.

Pervez, A.K.M.K, Gao, Q. and Uddin, M.E. (2015). Rural women's awareness on indigenous technical knowledge: case of northern Bangladesh. The Anthropologist, 21 (3) pp.415-426, https://doi.or $\mathrm{g} / 10.1080 / 09720073.2015 .11891831$

Pervez, A.K.M.K., Gao, Q., Zeng, Y. and Uddin.M.E. (2017). Hybrid rice: Bangladesh's failure and China's success. Journal of Agriculture and Ecology Research International, 10(1) pp.1-10., https://doi.org/10.9734/JAERI/2017/29384

Pervez, A.K.M.K., Uddin, M.E., Shah, A.A., Prodhan, F.A. and Sheikh, M.M. (2019). Fuzzy-Likert scale based assessment of marketing risk faced by the hybrid rice growers of Bangladesh. Ekonomikapoljoprivrede, 66 (1), pp.9-22, https://doi.org/10.5937/ekoPolj1901009K

Rivza, S.and Rivza, P. (2013). Fuzzy-ANP based research on the risk assessment of biogas production from agricultural biomass. In: Proceedings of international symposium on the analytical hierarchy process, pp. 23-26.

Rogers, W.A., Lamson N. and Rousseau, G.K. (2000). Warning research: An integrative perspective. Human Factors, 42 (1), pp. 102-139.

Ross, T.J. (2010).Fuzzy logic with engineering applications. West Sussex: John Wiley \& Sons. 
Salam, M., Siddique M.and Parvin, J. (2012). Assessment of technical efficiency of inbred HYV and hybrid ricecultivation at farm level. Bangladesh Journal of Agricultural Research, 37(2), pp.235-250.

Shah, M., Grant W. andStocklmayer, S. (2015). Farmers' perception of risk in cultivating hybrid rice in Bangladesh. South African Journal of Agricultural Extension, 43 (3), pp. 17-29, http://dx.doi. org/10.17159/2413-3221/2015/v43n2a338

Shahabuddin, Q. (2016). Food security prospects. The Daily Star 4 February 2016.

Singh, S., Bhati, P., Sharma, A. and Sahu, V. 2015. Super hybrid rice in China and India: current status and future prospects. International Journal of Agriculture and Biology, 17(2), pp. 221-232.

Skidmore, M. (2001). Risk, natural disasters, and household savings in a life cycle model. Japan and the World Economy, 13 (1), pp. 15-34,http://dx.doi.org/10.1016/S0922-1425(00)00056-6

Sorescu, A.B.and Spanjol, J. (2008). Innovation's effect on firm value and risk: Insights from consumer packaged goods. Journal of Marketing, 72 (2), pp.114-132.

Soussan, J. and Arriëns, W.L. (2004). Poverty and water security: understanding how water affects the poor.Manila: Asian Development Bank, http://hdl.handle.net/11540/2468.

Trong, P.H., Napasintuwong, O. (2015). Profit inefficiency among hybrid rice farmers in central Vietnam. Agriculture and Agricultural Science Procedia, 5, pp. 89-95,http://dx.doi. org/10.1016/j.aaspro.2015.08.013

Zakirah, O.andAbu, N.H. ( 2015). Southeast Asia Regional Conference on the System of Rice Intensification (SRI) 2015 Proceeding (SEA Regional Conference on the SRI 2015). 